\section{Juneberry Growth Is Affected by Weed Control Methods}

\author{
Deborah Willard ${ }^{1}$ and Harlene Hatterman Valenti ${ }^{1,2}$
}

AdDitionAL INDEX wORDs. saskatoon, weed management, mulches, flumioxazin, glyphosate, linuron, oryzalin, Amelanchier alnifolia

SUMMARY. Weed control is necessary to ensure success in early stages of juneberry (Amelanchier alnifolia) orchard development; however, juneberry growers have limited chemical weed control options. A field trial was initiated at Prosper, ND, to evaluate the efficacy of physical and chemical weed control methods and their effects on juneberry growth. Woven landscape fabric most effectively eliminated weed emergence, whereas winter rye (Secale cereale) cover crop allowed the most weeds to emerge throughout the study. During both years, a hairy vetch (Vicia villosa) companion crop provided poor early- to midseason weed control, but weed suppression increased over time as hairy vetch grew to cover open areas. However, hairy vetch was very competitive with juneberry, reducing crop height, width, and overall growth. Plants within the herbicide treatments (glyphosate at $0.75 \mathrm{lb} / \mathrm{acre}$ plus oryzalin at $2 \mathrm{lb} /$ acre and linuron at $1.7 \mathrm{lb} /$ acre followed by flumioxazin at $1 \mathrm{oz} /$ acre) and the hand-weeded control, which was weeded three times each year, had the greatest growth.

$\mathrm{J}$ uneberry is a small tree or large shrub valued for its delectable fruit. It is native to the southern Yukon and Northwest Territories, the Canadian prairies, and northern Great Plains as far south as Colorado and Nebraska (Harris, 1976). Juneberry has a variable growth habit, ranging from a low, spreading shrub to a narrow, erect, small tree. Originally used as an important food source by the North American Indians and early settlers, it is gaining acceptance as a commercial crop. Canada has led the way in large-scale production of juneberry. Juneberry orchards have been established in Saskatchewan since the 1980s and, slightly later, in Manitoba.

There are limited weed control options in juneberry orchards. Herbicides are not registered for established plantations of juneberry commercially grown for fruit production in North Dakota. Glyphosate may be used as a stale-bed treatment, and postemergence as a spot treatment for perennial weed control. The objective of this study was to evaluate the efficacy of various chemical and physical weed control methods during juneberry establishment.

This research was supported by the U.S. Department of Agriculture under Agreement 2006-38424-16847.

${ }^{1}$ Department of Plant Sciences, North Dakota State University, 166 Loftsgard Hall, Fargo, ND 58105

${ }^{2}$ Corresponding author. E-mail: h.hatterman.valenti@ ndsu.edu.

\section{Materials and methods}

Juneberry cultivar Parkhill was produced from stratified seed in Spring 2004 and transplanted on 2 June 2005 into a Bearden (finesilty, frigid, Aeric Calciaquoll)-Perella (fine-silty, mixed, frigid, Typic Haplaquoll) loam at the North Dakota State University research site near Prosper, ND. The experiment was arranged as a randomized complete-block design with eight weed control treatments and four replicates. Plants were transplanted on 2 -ft centers with $14 \mathrm{ft}$ between rows. Plots were a single row of 10 plants with $4 \mathrm{ft}$ between plots. Each treatment was applied to a $1.0-\mathrm{m}$-wide section of each plot, extending $0.5 \mathrm{~m}$ on either side of the juneberry row.

Treatments consisted of five physical methods [winter rye cover crop, hairy vetch cover crop, flax (Linum usitatissimum) straw mulch (FlaxTech, LLC, Rock Lake, ND), wheat (Triticum aestivum) straw mulch, and woven landscape fabric (The Tessman Co., Fargo, ND)] and two herbicide treatments (glyphosate at $0.75 \mathrm{lb} /$ acre plus oryzalin at $2 \mathrm{lb} /$ acre, and linuron at $1.7 \mathrm{lb} /$ acre in year 1 followed in by flumioxazin at $1 \mathrm{oz} /$ acre in year 2). A control group that received hand weeding three times each year was also included.

Winter rye seed was sown by hand at $300 \mathrm{lb} /$ acre in Sept. 2004 and 2005 . Emerged winter rye was sprayed with clethodim at $2 \mathrm{oz} /$ acre using a pump sprayer on 13 July 2005 and 15 May 2006, and mowed to a height of $8 \mathrm{~cm}$ on 1 Aug. 2005 and 15 June 2006. Winter rye was seeded at a high rate to achieve a dense stubble mulch to reduce weed emergence. Herbicide treatments were applied using a carbon dioxide-pressurized backpack sprayer with a $3-\mathrm{ft}$ sprayer boom equipped with three flat-fan nozzles (8002 XR; Spraying Systems Co., Wheaton, IL) spaced at 20 inches and calibrated to deliver 20 gal/acre at 40 psi. Herbicide treatments were applied on 16 May and 1 Aug. 2005, and 15 May and 14 July 2006. In 2006, flumioxazin was not applied with an adjuvant for the first spray date; however, on the second spray date, a petroleum oil-surfactant adjuvant (Loveland Products, Greeley, $\mathrm{CO}$ ), was included in the spray mixture at $1 \%$ (by volume). Juneberry plants were covered with tall, narrow, plastic cones during herbicide applications to prevent spray contact.

Treatments established on 15 June 2005 included hairy vetch seed sown at $55 \mathrm{lb} /$ acre, wheat straw spread to a uniform 3 -inch depth, flax straw mulch laid with a 2 -inch-diameter hole per plant, and landscape fabric laid with a 6-inch slit for each plant. Both the flax straw mulch and landscape fabric were secured at the

\begin{tabular}{llll}
\hline $\begin{array}{l}\text { Units } \\
\text { To convert U.S. to SI, } \\
\text { multiply by }\end{array}$ & U.S. unit & SI unit & $\begin{array}{l}\text { To convert SI to U.S., } \\
\text { multiply by }\end{array}$ \\
\hline 0.3048 & $\mathrm{ft}$ & $\mathrm{m}$ & 3.2808 \\
0.0929 & $\mathrm{ft}^{2}$ & $\mathrm{~m}^{2}$ & 10.7639 \\
9.3540 & gal/acre & ${\mathrm{L} \cdot h{ }^{-1}}^{-1}$ & 0.1069 \\
2.54 & inch $(\mathrm{es})$ & $\mathrm{cm}$ & 0.3937 \\
0.4536 & $\mathrm{lb}$ & $\mathrm{kg}$ & 2.2046 \\
1.1209 & $\mathrm{lb} / \mathrm{acre}$ & $\mathrm{kg} \cdot \mathrm{ha}^{-1}$ & 0.8922 \\
70.0532 & $\mathrm{oz} / \mathrm{acre}$ & $\mathrm{g} \cdot \mathrm{ha}^{-1}$ & 0.0143 \\
6.8948 & $\mathrm{psi}$ & $\mathrm{kPa}$ & 0.1450 \\
$\left({ }^{\circ} \mathrm{F}-32\right) \div 1.8$ & ${ }^{\circ} \mathrm{F}$ & ${ }^{\circ} \mathrm{C}$ & $\left(1.8 \times{ }^{\circ} \mathrm{C}\right)+32$
\end{tabular}


edges with 8 -inch-long sod staples. The roll of flax straw mulch consists of shredded flax straw that has a binding substance added before forming a mat $\approx 0.5$ inch thick. On 15 May 2006, hairy vetch seed was sown at $55 \mathrm{lb} /$ acre and wheat straw was added again to reach the initial depth.

Weeds in 2005 were removed on 1 Aug. from all experimental units except the chemical treatments, and from all experimental units on 1 Sept. and 1 Oct. Data collected during weed removal included the number of broadleaf and grass weeds and time required to remove the weeds. In 2006 , weeds were removed from all experimental units except the chemical treatments on 14 July, and from all experimental units on 15 June and 15 Aug. Data collected during weed removal in 2006 included the number of broadleaf and grass weeds, weed fresh weight, and time required to remove the weeds. On 2 Sept. 2006, juneberry height, width, stems per plant, and total length of main and secondary branches were measured for the middle six plants from each experimental unit.

Values were averaged within each experimental unit. Data were subjected to analysis of variance to test for single-factor effects. Weed control treatments were considered fixed effects, whereas year was considered a random variable. Means were separated with Fisher's protected LSD test at $P \leq 0.05$.

\section{Results and discussion}

WeEd control. Weed control data were analyzed separately by year. The years were not combined because 2005 was considered the year of crop establishment, resulting in later application timings, so data were collected later in the season compared with 2006. Grass populations in 2005 and 2006 in all treatments were minor; however, the five most common broadleaf weeds found in all plots were common purslane (Portulaca oleracea), redroot pigweed (Amaranthus retroflexus), dandelion (Taraxacum officinale), common lambsquarters (Chenopodium album), and canada thistle (Cirsium arvense).

Broadleaf weed control in 2005 and 2006 was greatest with the landscape fabric treatment and low with winter rye (Tables 1 and 2 ). Winter rye was seeded at a high rate; however, poor germination resulted in a sparse crop residue that allowed a high population of dandelion to establish. Similarly, during both years, hairy vetch grew slowly so gaps in the thin plant canopy allowed numerous common purslane to emerge. Hairy vetch, as it continued to grow through each growing season, formed an increasingly dense mat that blocked irradiance, thereby increasing its ability to reduce seed germination. Teasdale and Daughtry (1993) concluded that live hairy vetch reduced red light transmittance, which reduced the red-to-far red ratio to reduce phytochromemediated seed germination.

The flax straw mulch mat deteriorated very little so it continued to be as effective as the landscape fabric in weed suppression throughout the 2 -year study (Tables 1 and 2 ). Wheat straw provided weed control similar to the landscape fabric treatment in Aug. 2005, but weed control was reduced by September and October, and was similar to the untreated control. This reduction may have occurred as a result of barrier disturbance when weeds were removed in August. In 2006, broadleaf weed numbers in the wheat straw treatment were similar to the landscape fabric treatment in June, July, and August. Additional care was taken after each weed removal to restore the straw barrier, which may have helped reduce the number of broadleaf weeds during the second and third month of evaluation compared with 2005. However, through the course of the growing season, some straw was wind blown, which reduced the 3 -inch straw layer and resulted in a thinner layer of mulch that was less effective in weed suppression. Hipps et al. (2004) reported little weed emergence with a 15 -cm-deep straw mulch treatment, whereas Cushman et al. (2005) reported excellent weed control with wheat straw at 7.5- and $15-\mathrm{cm}$ depths, and recommended a mulch depth of $7.5 \mathrm{~cm}$ because of its lower cost. A thinner wheat straw layer was used in the current study because of concerns of retaining too much moisture with the fine-textured soil and the lower soil temperature effect of plant growth. Where wind makes it difficult to maintain a 3 -inch wheat straw layer throughout the season, additional straw will be needed to provide more effective weed control.

Glyphosate plus oryzalin in 2005 provided excellent broadleaf weed control for 1 month, and linuron for 2 months, after herbicide application (Table 1). Similarly, in 2006, glyphosate plus oryzalin provided effective weed control 1 month after each spray application (Table 2). However, broadleaf and grass counts after the first flumioxazin treatment were similar to those from the untreated control. Flumioxazin on the first spray date was applied without an adjuvant and the broadleaf weeds were beyond the four-leaf stage, which provide inadequate control. Flumioxazin on the second spray date was applied at the same rate, but with a petroleum oil-surfactant adjuvant, which killed the small, emerged weeds and provided some residual weed control. Thus, in August, the number of weeds was significantly less than the untreated plot. Still, the majority of the large broadleaf weeds were not controlled by flumioxazin even with the adjuvant. Herbicide treatments were reapplied in Aug. 2005 and in July 2006, so weeds were not removed from the herbicide-treated plots during those months. Thus, statistical analysis of time required to hand weed was only performed on the six nonherbicide treatments.

Time required for hand weeding throughout 2005 was greatest in the winter rye treatment and least in the landscape fabric treatment (Table 1). Weed escapes did not occur in 2006 in the landscape fabric treatment; however, extensive time was required for weed removal in the hairy vetch treatment in June and July and in the winter rye treatment in August (Table 2 ). Considerable care was required to remove weeds without disturbing the hairy vetch and winter rye mulch.

In June and Aug. 2006, the ineffectiveness of flumioxazin allowed large weeds to continue to grow after herbicide application, thus accounting for the high fresh weight (Table $2)$. The landscape fabric treatment had the lowest weed fresh weight as well as the lowest grass and broadleaf weed counts during each month of 2006.

JUNEBERRY GROWTH. Juneberry growth varied greatly among 
Table 1. Effect of physical and herbicidal weed control treatments during juneberry establishment on grass and broadleaf weed densities, and time required for hand weeding at three evaluation times in 2005 at Prosper, ND.

\begin{tabular}{|c|c|c|c|}
\hline $\begin{array}{l}\text { Time of evaluation } \\
\text { and treatment }\end{array}$ & $\begin{array}{c}\text { Grasses } \\
(\text { no. } / \text { plot })^{\mathrm{z}}\end{array}$ & $\begin{array}{l}\text { Broadleaves } \\
(\text { no. } / \text { plot })^{\mathrm{z}}\end{array}$ & $\begin{array}{l}\text { Hand weeding } \\
\text { (min/plot) }\end{array}$ \\
\hline \multicolumn{4}{|l|}{ August evaluation } \\
\hline Wheat straw & 5 & 80 & 6 \\
\hline Landscape fabric & 0 & 0 & 0 \\
\hline Hairy vetch & 15 & 220 & 12 \\
\hline Flax mulch & 0 & 10 & 1 \\
\hline Winter rye & 2 & 260 & 13 \\
\hline Glyphosate + oryzalin ${ }^{y}$ & 11 & 110 & $-^{x}$ \\
\hline Linuron $^{w}$ & 7 & 130 & - \\
\hline Untreated control & 10 & 300 & 11 \\
\hline $\operatorname{LSD}_{0.05}{ }^{\mathrm{v}}$ & 10 & 130 & 5 \\
\hline \multicolumn{4}{|l|}{ September evaluation } \\
\hline Wheat straw & 8 & 120 & 5 \\
\hline Landscape fabric & 0 & 0 & 0 \\
\hline Hairy vetch & 4 & 100 & 5 \\
\hline Flax mulch & 1 & 0 & 0 \\
\hline Winter rye & 4 & 195 & 8 \\
\hline Glyphosate + oryzalin & 8 & 10 & 0 \\
\hline Linuron & 8 & 25 & 0 \\
\hline Untreated control & 15 & 150 & 6 \\
\hline $\mathrm{LSD}_{0.05}$ & 7 & 80 & 4 \\
\hline \multicolumn{4}{|l|}{ October evaluation } \\
\hline Wheat straw & 0 & 35 & 1 \\
\hline Landscape fabric & 0 & 0 & 0 \\
\hline Hairy vetch & 0 & 2 & 0 \\
\hline Flax mulch & 0 & 2 & 0 \\
\hline Winter rye & 0 & 102 & 2 \\
\hline Glyphosate + oryzalin & 0 & 82 & 1 \\
\hline Linuron & 0 & 27 & 1 \\
\hline Untreated control & 0 & 64 & 1 \\
\hline $\mathrm{LSD}_{0.05}$ & $\mathrm{NS}^{\mathrm{v}}$ & 39 & 1 \\
\hline
\end{tabular}

${ }^{\mathrm{z}}$ Plot area was $6 \mathrm{~m}^{2}\left(64.6 \mathrm{ft}^{2}\right)$.

${ }^{y}$ Glyphosate was applied at $0.75 \mathrm{lb} /$ acre $\left(0.841 \mathrm{~kg} \cdot \mathrm{ha}^{-1}\right)$ and oryzalin at $2 \mathrm{lb} / \mathrm{acre}\left(2.2 \mathrm{~kg} \cdot \mathrm{ha}^{-1}\right)$ on 16 May and l Aug. 2005.

${ }^{x}$ Herbicide treatments were reapplied in August, so weeds were not removed from the herbicide-treated plots that month.

"Linuron was applied at $1.5 \mathrm{lb} /$ acre $\left(1.68 \mathrm{~kg} \cdot \mathrm{ha}^{-1}\right)$ on 16 May and 1 Aug. 2005.

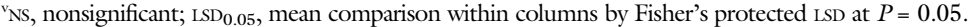

treatments, with the greatest height, width, stem number, and length of main and secondary branches in the untreated plot, followed by the herbicide treatments (Table 3 ). Juneberry was least successful in the flax mulch, straw mulch, and hairy vetch treatments. Reduced juneberry growth in the flax and straw mulch treatments was attributed to an altered soil environment and a decrease in available soil nitrogen $(\mathrm{N})$ from increased utilization by soil microbes. St-Pierre and Tulloch (2002) reported greater juneberry growth when grown in black plastic compared with those grown in wood chips, and attributed the growth difference to the cooler soil temperature under the layer of wood chips in comparison with the black plastic because both conserved soil moisture. Ferguson and Gorby (1964) reported that addition of organic residues with a wide carbonto-nitrogen $(\mathrm{C}: \mathrm{N})$ ratio lowered the inorganic soil $\mathrm{N}$ content. Grain straw has a $\mathrm{C}: \mathrm{N}$ ratio of $\approx 80: 1$ (Havlin et al., 2005,) and the flax mulch used in this study had a $\mathrm{C}: \mathrm{N}$ ratio of $60: 1$. The lack of mulch incorporation into the soil should have reduced soil $\mathrm{N}$ utilization by soil microbes. However, Cong et al. (2006) showed that differences in microbial biomass and activity do occur with straw surface mulching, although they also contributed to differences to soil moisture and temperature differences.

Reduced juneberry growth in the hairy vetch treatment was attributed to excessive competition by the cover crop. Teasdale (1996) reported that a cover crop that is aggressive enough to prevent weed emergence may suppress the desired crop. By the end of each growing season, juneberry plants were completely covered by hairy vetch foliage.

Although interspecies plant competition was not present in the landscape fabric treatment, juneberry plants did not perform as well as in other treatments in which periodic weed competition existed (Table 3 ). Plant height and width was reduced $\approx 25 \%$ compared with plants in the untreated control (hand weeded monthly for 3 months). In addition, there was more than $40 \%$ stem reduction/plant and $60 \%$ shorter main and secondary branches compared with plants in the untreated control.

Reduction in juneberry growth was attributed to the stress incited by the warm microclimate from the dark-colored, reflective landscape fabric. Miller and Greene (2003) reported that reflective films placed at orchard floors can increase plant canopy temperatures up to $19.8^{\circ} \mathrm{F}$ compared with plots without reflective film. St-Pierre and Tulloch (2002) reported greater juneberry growth when grown in black plastic compared with those grown in wood chips or without mulch, even though plants suffered from sun scald. Black plastic conserves soil moisture more than fabric mulch, thereby influencing tree growth differently (Appleton et al., 1990).

\section{Conclusion}

This study showed that maintaining a weed-free environment during the first 2 years of juneberry establishment did not result in optimum plant growth as observed with the landscape fabric. It is presumed that the soil water content and microclimate air temperature differences contributed to the reduced juneberry growth in the landscape fabric treatment of our research. Therefore, utilization of landscape fabric during juneberry establishment should be avoided, especially when optimum juneberry growth and ultimately hastened fruit production is the goal of the producer. However, if a weedfree environment and the aesthetics associated with the lack of weed 
Table 2. Effect of physical and herbicidal weed control treatments during juneberry establishment on grass and broadleaf weed densities, time required for hand weeding, and weed fresh weight at three evaluation times in 2006 at Prosper, ND.

\begin{tabular}{|c|c|c|c|c|}
\hline $\begin{array}{l}\text { Time of evaluation } \\
\text { and treatment }\end{array}$ & Grasses & $\begin{array}{l}\text { Broadleaves } \\
(\text { no. } / \text { plot })^{z}\end{array}$ & $\begin{array}{l}\text { Hand weeding } \\
(\mathrm{min} / \mathrm{plot})^{\mathrm{z}}\end{array}$ & $\begin{array}{r}\text { Weed } \\
\text { wt (kg) }\end{array}$ \\
\hline \multicolumn{5}{|l|}{ June evaluation } \\
\hline Wheat straw & 7 & 120 & 10 & 1 \\
\hline Landscape fabric & 0 & 0 & 0 & 0 \\
\hline Hairy vetch & 29 & 1140 & 45 & 4 \\
\hline Flax mulch & 1 & 30 & 6 & 1 \\
\hline Winter rye & 2 & 80 & 17 & 1 \\
\hline Glyphosate + oryzalin ${ }^{\mathrm{x}}$ & 2 & 10 & 4 & 1 \\
\hline Flumioxazin ${ }^{w}$ & 7 & 380 & 19 & 10 \\
\hline Untreated control & 7 & 300 & 20 & 3 \\
\hline $\operatorname{LSD}_{0.05^{\mathrm{v}}}$ & 14 & 200 & 12 & 2 \\
\hline \multicolumn{5}{|l|}{ July evaluation } \\
\hline Wheat straw & 4 & 115 & 13 & 3 \\
\hline Landscape fabric & 0 & 0 & 0 & 0 \\
\hline Hairy vetch & 4 & 140 & 24 & 5 \\
\hline Flax mulch & 3 & 50 & 9 & 2 \\
\hline Winter rye & 4 & 140 & 18 & 2 \\
\hline Glyphosate + oryzalin & 1 & 105 & $-^{\mathrm{u}}$ & 一 \\
\hline Flumioxazin & 2 & 80 & - & - \\
\hline Untreated control & 4 & 210 & 21 & 5 \\
\hline $\mathrm{LSD}_{0.05}$ & $\mathrm{NS}^{\mathrm{v}}$ & 70 & 10 & 2 \\
\hline \multicolumn{5}{|l|}{ August evaluation } \\
\hline Wheat straw & 1 & 90 & 21 & 3 \\
\hline Landscape fabric & 0 & 0 & 0 & 0 \\
\hline Hairy vetch & 1 & 70 & 25 & 4 \\
\hline Flax mulch & 1 & 70 & 14 & 2 \\
\hline Winter rye & 5 & 640 & 47 & 8 \\
\hline Glyphosate + oryzalin & 1 & 70 & 16 & 2 \\
\hline Flumioxazin & 5 & 150 & 40 & 11 \\
\hline Untreated control & 3 & 310 & 27 & 5 \\
\hline $\mathrm{LSD}_{0.05}$ & 3 & 120 & 13 & 2 \\
\hline
\end{tabular}

zPlot area was $6 \mathrm{~m}^{2}\left(64.6 \mathrm{ft}^{2}\right)$.

${ }^{y} 1 \mathrm{~kg}=2.2046 \mathrm{lb}$.

${ }^{x}$ Glyphosate was applied at $0.75 \mathrm{lb} /$ acre $\left(0.841 \mathrm{~kg} \cdot \mathrm{ha}^{-1}\right)$ and oryzalin at $2 \mathrm{lb} / \mathrm{acre}\left(2.2 \mathrm{~kg} \cdot \mathrm{ha}^{-1}\right)$ on $15 \mathrm{May}$ and 14 July 2006.

"Flumioxazin was applied at $1 \mathrm{oz} /$ acre $\left(0.07 \mathrm{~kg} \cdot \mathrm{ha} \mathrm{a}^{-1}\right)$ on 15 May and $14 \mathrm{July} 2006$.

${ }^{\mathrm{V}} \mathrm{LS}_{0.05}$, mean comparison within columns by Fisher's protected LSD at $P=0.05$; NS, nonsignificant.

${ }^{u}$ Herbicide treatments were reapplied in July, so weeds were not removed from the herbicide-treated plots that month.

Table 3. Effect of physical and herbicidal weed control treatments during juneberry establishment on plant height, width, stem number, and length of main and secondary branches as determined in Fall 2006 at Prosper, ND.

\begin{tabular}{|c|c|c|c|c|}
\hline$\underline{\text { Treatment }}$ & $\mathrm{Ht}(\mathrm{cm})^{\mathrm{z}}$ & $\begin{array}{l}\text { Width } \\
(\mathrm{cm})\end{array}$ & $\begin{array}{c}\text { Stems } \\
\text { (no./plant) }\end{array}$ & $\begin{array}{l}\text { Length of main } \\
\text { and secondary } \\
\text { branches }(\mathrm{cm})\end{array}$ \\
\hline Straw & 40 & 45 & 5 & 300 \\
\hline Landscape fabric & 44 & 45 & 4 & 420 \\
\hline Hairy vetch & 40 & 40 & 4 & 170 \\
\hline Flax mulch & 39 & 43 & 3 & 250 \\
\hline Winter rye & 47 & 51 & 5 & 490 \\
\hline Glyphosate +oryzalin ${ }^{y}$ & 52 & 62 & 5 & 960 \\
\hline Linuron/flumioxazin ${ }^{x}$ & 53 & 59 & 6 & 960 \\
\hline Untreated control & 59 & 63 & 7 & 1060 \\
\hline$\underline{L S D}_{0.05}{ }^{\mathrm{w}}$ & 9 & 12 & 2 & 130 \\
\hline
\end{tabular}

${ }^{\mathrm{z}} 1 \mathrm{~cm}=0.3937$ inch

ylyphosate was applied at $0.75 \mathrm{lb} /$ acre $\left(0.841 \mathrm{~kg} \cdot \mathrm{ha}^{-1}\right)$ and oryzalin at $2 \mathrm{lb} / \mathrm{acre}\left(2.2 \mathrm{~kg} \cdot \mathrm{ha}^{-1}\right)$ on $16 \mathrm{May}$ and 1 Aug. 2005, and 15 May and 14 July 2006.

${ }^{x}$ Linuron was applied at $1.5 \mathrm{lb} /$ acre $\left(1.68 \mathrm{~kg} \cdot \mathrm{ha}^{-1}\right)$ on 16 May and $\mathrm{l} \mathrm{Aug.} \mathrm{2005,} \mathrm{and} \mathrm{flumioxazin} \mathrm{was} \mathrm{applied} \mathrm{at}$ $\mathrm{loz} /$ acre $\left(0.07 \mathrm{~kg} \cdot \mathrm{ha}^{-1}\right)$ on 15 May and 14 July 2006.

${ }^{\mathrm{w}_{\mathrm{LSD}}} \mathrm{D}_{0.05}$, mean comparison within columns by Fisher's protected LSD at $P=0.05$ growth within a juneberry row is desired, then the use of landscape fabric would be most appropriate. Similarly, the use of straw mulch during juneberry establishment should be avoided if optimum growth is desired.

Utilization of a winter rye cover crop or a hairy vetch companion crop in general provided poor weed control either early or late during the growing season and resulted in reduced juneberry growth. Linuron is registered for use on juneberry during establishment in Canada, but not in the United States. Glyphosate is registered for use on juneberry for preplant, spot, and directed-spray applications. Flumioxazin and oryzalin are not registered for use on juneberry. More research is needed to identify safe and effective herbicides for use during juneberry establishment. Likewise, additional research is needed to investigate the effect of the weed control methods, used in the current study, on juneberry growth and fruit production in an established orchard to determine whether these weed control methods will cause similar results to mature plants.

\section{Literature cited}

Appleton, B.L., J.F. Derr, and B.B. Ross. 1990. The effect of various landscape weed control measures on soil moisture and temperature, and tree root growth. J. Arboriculture 16:264-268.

Cong, T., J.B. Ristaino, and H. Shuijin. 2006. Soil microbial biomass and activity in organic tomato farming systems: Effects of organic inputs and straw mulching. Soil Biol. Biochem. 38:246-255.

Cushman, K.E., M. Maqbool, and P.D. Gerard. 2005. Mulch type, mulch depth, and rhizome planting depth for fieldgrown american mayapple. HortScience 40:635-639.

Ferguson, W.S. and B.J. Gorby. 1964. Effect of straw on availability of nitrogen to cereal crops. Can. J. Soil Sci. 44: 286-291.

Harris, R.E. 1976. The Saskatoon: Canada's national fruit. Can. Agr. 21:28-29.

Havlin, J.L., J.D. Beaton, S.L. Tisdale, and W.L. Nelson. 2005. Soil fertility and fertilizers, an introduction to nutrient management. 7th ed. Prentice Hall, Upper Saddle River, NJ. 
Hipps, N.A., M.J. Davies, and D.S. Johnson. 2004. Effects of different ground vegetation management systems on soil quality, growth and fruit quality of culinary apple trees. J. Hort. Sci. Biotechnol. 79:610-618.

Miller, S.S. and G.M. Greene. 2003. The use of reflective film and Ethephon to improve red skin color of apples in the mid-Atlantic region of the United States. HortTechnology 13:90-99.

St-Pierre, R.G. and H. Tulloch. 2002. Maximizing root development for enhanced survival and establishment of saskatoons. Praire Fruit J. 9: $3-4$.
Teasdale, J.R. 1996. Contribution of cover crops to weed management in sustainable agricultural systems. J. Production Agr. 9:475-479.

Teasdale, J.R. and C.S.T. Daughtry. 1993. Weed suppression by live and desiccated hairy vetch (Vicia villosa). Weed Sci. 41:207-212. 